\title{
ANALISIS FAKTOR-FAKTOR YANG MEMPENGARUHI KEPESERTAAN PROGRAM JAMINAN KESEHATAN NASIONAL PADA PEKERJA INFORMAL PERKOTAAN
}

\author{
Farid Subkhan \\ Perbanas Institute \\ Jl. Perbanas, Karet Kuningan, Setiabudi, Jakarta Selatan, DKI Jakarta 12940 \\ Email: farid.subkhan@perbanas.id
}

\begin{abstract}
National Health Insurance (JKN) was born as mandated by Law No. 40 of 2004 on National Social Security System (SJSN) and the Law No. 24 of 2011 on National Social Security Agency which appointed PT. Askes (Persero) which is then referred to BPJS Kesehatan, followed by Presidential Decree No. 12 of 2013 and Presidential Decree No. 111 of 2013 which has mandated that all Indonesian citizens must be incorporated in JKN program no later than January 1st, 2019. The main challenge is how to attract uninsured people to participate in JKN program within the targeted timeframe. This study examine the probability of urban informal workers as the main target of uninsured people to participate in JKN program based on ten independent variables that are price stimulus, discounts stimulus, payment period stimulus, precautionary motive, access motive, and financial planning knowledge which includes risk management, saving management, retirement planning, heirs planning, and household cash flow management. The study was conducted through direct interviews in Greater Jakarta to 150 informal workers. The results of the study indicate that discount stimulus, access motive to insurance, practicing cash flow management, and heirs planning have significant impact to the person's interest on JKN program.
\end{abstract}

Keywords: National Health Insurance (JKN), Social Security, Stimulus, Motives, Financial Planning.

ABSTRAK
Jaminan Kesehatan Nasional (JKN) lahir sebagai amanat UU No. 40 Tahun 2004 tentang Sistem Jaminan Sosial Nasional (SJSN) serta UU No. 24 Tahun 2011 tentang Badan Penyelenggara Jaminan Sosial Nasional yang menunjuk PT. Askes (Persero), selanjutnya disebut BPJS Kesehatan, kemudian ditindaklanjuti dengan Perpres No. 12 Tahun 2013 dan Perpres No. 111 Tahun 2013 telah mengamanatkan bahwa seluruh warga negara Indonesia harus sudah tergabung dalam program JKN selambat-lambatnya tanggal 1 Januari 2019. Tantangannya adalah bagaimana membuat orang-orang yang tidak terlindungi bersedia menjadi peserta JKN dalam target waktu yang ditentukan. Studi ini menguji probabilitas seorang pekerja sektor informal perkotaan sebagai target utama penduduk yang tidak terlindungi asuransi untuk menjadi peserta JKN berdasarkan sepuluh variabel bebas yaitu stimulus harga, stimulus diskon, stimulus periode pembayaran, precautionary motive, access motive dalam membeli asuransi, pengetahuan tentang financial planning yang meliputi manajemen risiko, manajemen menabung, perencanaan hari tua, perencanaan waris, dan manajemen cash flow rumah tangga. Penelitian dilakukan melalui wawancara langsung di wilayah Jabodetabek terhadap 150 pekerja sektor informal. Hasil penelitian mengindikasikan empat variabel bebas memiliki pengaruh yang signifikan terhadap probabilitas seseorang menjadi peserta JKN yaitu stimulus diskon, access motive dalam membeli asuransi, manajemen cash flow dan perencanaan harta waris.

Kata kunci: Jaminan Kesehatan Nasional (JKN), Social Security, Stimulus, Motives, Financial Planning.

\section{PENDAHULUAN}

Persoalan perlindungan kesehatan bagi seluruh rakyat Indonesia memiliki sejarah yang panjang. Sebelum diterbitkannya UU
No. 40 Tahun 2004 tentang Sistem Jaminan Sosial Nasional (SJSN), perlindungan kesehatan seolah-olah hanya menjadi persoalan individu yang sifatnya komersial. 
UU No. 40 Tahun 2004 menugaskan empat lembaga untuk menjalankan fungsi sebagai Badan Penyelenggara Jaminan Sosial. Keempat lembaga tersebut adalah JAMSOSTEK, TASPEN, ASABRI, dan ASKES.

Setelah UU tentang Jaminan Sosial mengalami kemandegan cukup lama, akhirnya melalui UU No. 24 tahun 2011, pemerintah telah mengesahkan UU tentang Badan Penyelenggara Jaminan Sosial. Dalam undang-undang ini pemerintah telah mengamanatkan kepada PT. Askes (Persero) sebagai Badan Penyelenggara Jaminan Sosial (BPJS) untuk jaminan kesehatan dan PT Jamsostek sebagai BPJS untuk Jaminan Sosial Ketenagakerjaan yang meliputi kecelakaan kerja, hari tua, pensiun, dan kematian.

Studi mengenai JKN telah dilakukan sebelumnya oleh LPEM FE UI (2014), khususnya kepada pekerja informal perkotaan diluar Jabodetabek dan menekankan pada aspek willingness to pay. Sebagai tindak lanjut dari penelitian LPEM FE UI tersebut, diperlukan penelitian lebih lanjut untuk mengenai faktor-faktor apa sajakah yang menentukan minat pekerja informal perkotaan terhadap program JKN, khususnya di Jabodetabek. Dengan mengetahui faktor-faktor yang mempengaruhi keputusan pekerja informal terhadap program JKN, diharapkan dapat membantu pemerintah dalam melakukan intervensi kebijakan untuk keberhasilan program JKN. Tujuan penelitian ini adalah untuk melakukan identifikasi terhadap faktor-faktor yang mempengaruhi minat pekerja informal perkotaan terhadap program JKN yang diselenggarakan oleh BPJS Kesehatan, khususnya di Jabodetabek.

\section{TINJAUAN PUSTAKA}

\subsection{Risiko Dalam Asuransi}

Persoalan mendasar yang sering muncul dalam akuisisi atau kepesertaan program atau jasa asuransi adalah informasi asimetris (assymetric information). Arvidsson (2010) menyebutkan bahwa informasi asimetris selalu ada didalam setiap transaksi antara dua pihak. Jika tidak terjadi pada keduanya, minimal terjadi pada salah satu pihak. Hal ini karena misalnya dalam transaksi jual dan beli. Seorang pembeli biasanya tidak mengetahui secara pasti tentang produk yang dibeli, sementara seorang penjual juga tidak tahu pasti tentang kemampuan pembelinya. Disini akan timbul persepsi dan harapan yang berbeda antara pembeli dan penjual karena keterbatasan informasi.

\subsection{Asuransi dan Perencanaan Keuangan}

Black dan Skipper (1994) menjelaskan mengenai 6 (enam) elemen perencanaan keuangan dan pemanfaatan asuransi jiwa dan kesehatan untuk membantu seseorang mencapai tujuannya. Ke-enam elemen tersebut adalah sebagai berikut:

1. Membuat perencanaan manajemen resiko.

2. Membuat program menabung atau berinvestasi.

3. Menyiapkan masa pension.

4. Mengelola pajak.

5. Merencanakan warisan.

6. Mengelola cash flow keluarga.

\subsection{Asuransi Kesehatan}

Asuransi kesehatan sebagaimana dijelaskan oleh Black dan Skipper (1994) disebut juga dengan asuransi kecelakaan dan kesehatan, asuransi kecelakaan dan sakit, dan asuransi disability atau cacat tetap. Pada prinsipnya asuransi kesehatan selalu dikaitkan dengan dua hal yaitu biaya perawatan medis atau medical expense insurance dan disability income insurance atau asuransi untuk perlindungan karena hilangnya pendapatan seseorang karena cacat tetap. Pada jenis asuransi yang kedua ini, perusahaan asuransi akan terus melakukan pembayaran atas biaya premi 
karena peserta asuransi tersebut kehilangan pendapatan karena kecelakaan atau sakit.

Berdasarkan targetnya, sebagaimana dijelaskan oleh Black dan Skipper (1994), asuransi kesehatan dibagi menjadi dua yaitu individual health insurance atau asuransi individual dan group health insurance atau asuransi kelompok. Asuransi individu diciptakan khusus untuk memberikan perlindungan pemeliharaan kesehatan seorang individu sebagai peserta, sedangkan asuransi kelompok dikelola untuk memberikan perlindungan pemeliharaan kesehatan atas sekelompok individu didalam satu kontrak.

\subsection{Manfaat Asuransi Kesehatan}

Asuransi kesehatan untuk individu pada umumnya menanggung biaya pemeliharaan atau perawatan medis yang meliputi biaya bedah yang meliputi: biaya kamar, biaya rupa-rupa, biaya rawat jalan untuk diagnosa x-ray dan biaya laboratorium, biaya melahirkan, biaya pembedahan, dan biaya tenaga medis lainnya (Black dan Skipper, 1994).

\subsection{Asuransi Jaminan Sosial}

Asuransi Jaminan Sosial atau social security memberikan perlindungan untuk risiko yang bersifat ekonomis dan risiko sosial secara kolektif (Kertonegoro, 1987). Lebih jauh Kertonegoro menjelaskan bahwa jaminan sosial memberikan manfaat terbatas pada pemenuhan kebutuhan dasar manusia, dan minimal untuk menjaga harkat dan martabatnya. Pemenuhan ini menjadi tanggungjawab pemerintah atau swadaya dari masyarakat karena pada prinsipnya jaminan sosial tidak dapat dilakukan secara individual. Dengan terpenuhinya kebutuhan dasar setiap penduduk, diharapkan dapat membantu mereka untuk memikirkan kebutuhan yang lain yang lebih tinggi tingkatannya.

\subsection{Asuransi Kesehatan Sosial dan Pembangunan}

Berbagai studi sebelumnya telah banyak dilakukan untuk mengukur dampak dari sistem jaminan sosial nasional, termasuk jaminan kesehatan sosial terhadap pembangunan. Kertonegoro (1987) menyebutkan bahwa jaminan sosial memiliki peranan penting dalam: (1) pemerataan baik dalam hal pendapatan maupun penanggulangan risiko, (2) pertumbuhan ekonomi yang diakibatkan oleh peningkatan konsumsi rumah tangga (peningkatan permintaan), pembentukan modal dan investasi, (3) stabilitas nasional yang meningkat karena terciptanya ketentraman masyarakat.

\subsection{Jaminan Kesehatan Nasional (JKN)}

Sistem jaminan kesehatan nasional (JKN) hadir di Indonesia sebagai bagian dari amanah UUD 1945 hasil amandemen tahun 2002 yang mewajibkan negara untuk mengembangkan sistem jaminan sosial bagi seluruh rakyat Indonesia. Melalui UU No. 40 Tahun 2004 tentang Sistem Jaminan Sosial Nasional, negara telah menetapkan dibentuknya Sistem Jaminan Sosial Nasional (SJSN) yang bertujuan untuk memberikan jaminan terpenuhinya kebutuhan dasar hidup yang layak bagi peserta jaminan sosial dan atau keluarganya. Sistem jaminan sosial ini dibentuk berdasarkan prinsip-prinsip: kegotong-royongan, nirlaba, keterbukaan, kehati-hatian, akuntabilitas, portabilitas, bersifat wajib, amanat, dan hasil dananya dikelola untuk pengembangan program yang dimanfaatkan sebesar-besarnya untuk kepentingan peserta.

\subsection{Keputusan Pembelian Asuransi}

Sebagaimana dijelaskan oleh Chaudhuri (2006), bahwa sebuah produk dipilih oleh seseorang karena memiliki rational values dan emotional values. 
Solomon (2013) mendefiniskan perilaku konsumen sebagai sebuah proses dimana seseorang atau sekelompok orang memilih, membeli, menggunakan, memiliki suatu produk, jasa, ide, atau pengalaman untuk memenuhi kebutuhan dan keinginannya. Beberapa faktor yang melatarbelakangi perbedaan tersebut diantaranya adalah karena faktor usia, jenis kelamin, status perkawinan, jumlah anak atau tanggungan serta umur anaknya, jenis kelamin anak dan lain-lain. Faktor berikutnya adalah kelas sosial dan pendapatan, selain itu disebutkan bahwa perilaku seseorang juga dipengaruhi oleh ras dan etnik, faktor geografi, dan gaya hidup.

\subsection{Motif Pembelian Asuransi} Kesehatan

Mahdzan dan Victorian (2013) telah meneliti tentang motif seseorang dalam memiliki produk asuransi jiwa sebagai bagian dari upaya menabung untuk empat tujuan yaitu motif berjaga-jaga (Hubbard et al.,1995), motif untuk menghadapi siklus kehidupan baru dimasa yang akan datang (Modigliani \& Brumberg, 1954), motif untuk menyiapkan warisan (Bernheim, Shleiferand, \& Summers, 1985), dan motif untuk mengumpulkan kekayaan (Keynes, 1936).

\section{METODE PENELITIAN}

\subsection{Model Penelitian}

Berdasarkan telaah pustaka dan pola pikir penelitian, secara umum ketertarikan seseorang untuk menjadi peserta Jaminan Kesehatan Nasional (JKN) atau BPJS Kesehatan dalam penelitian ini dipengaruhi oleh faktor stimulus harga, stimulus diskon, stimulus periode pembayaran, precautionary motive dan access motive pembelian asuransi, dan pengetahuan tentang financial planning (risk management, saving management, retirement plan, heirs plan, cash flow management). Di luar faktor tersebut beberapa faktor demografi juga dijadikan sebagai variabel kontrol yang juga diuji untuk melihat pengaruhnya terhadap minat seseorang untuk menjadi peserta JKN. Secara rinci, model penelitian ini dapat dijelaskan sebagai berikut:

$J K N_{\mathrm{i}}=f$ (Stimprice, Stimdiscount, Stimpayterm, Premotive, Accessmotive, risk, saving, retirement, heirs, cashflow, Sex, Age, Dependant, SEC, Edu, Occupation, Ethnicity).

\subsection{Sampel Penelitian}

Kriteria responden dalam penelitian ini adalah sebagai berikut:

1. Warga Negara Indonesia usia 17 tahun keatas;

2. Belum menjadi peserta JKN atau BPJS Kesehatan atau asuransi kesehatan apapun;

3. Memiliki pekerjaan atau penghasilan;

4. Bekerja di sektor informal (tidak mendapatkan fasilitas BPJS Kesehatan atau asuransi kesehatan dari pemberi kerja);

5. Tinggal di wilayah perkotaan (Jabodetabek).

Dengan asumsi jumlah populasi nonpeserta JKN dari sektor informal perkotaan di Jabodetabek yang tidak diketahui, margin of error sebesar $8 \%$ dan confidence level $95 \%$, penelitian ini melibatkan minimal 150 responden. Mengacu pada Henshe, Rose, \& Greene (2005), pengambilan sampel minimum dapat diambil dengan mengalikan jumlah alternatif pilihan responden dengan 50 . Dengan variabel ketertarikan terhadap JKN antara Ya dan Tidak, maka minimum sampel 100 sudah dianggap cukup. Beaton \& Cao (1996) menyebutkan bahwa sampel sebanyak 100 hingga 200 responden sudah mampu menghasilkan estimasi parameter yang stabil. Mengacu pada berbagai pendapat tersebut, penelitian ini melibatkan 150 responden pekerja sektor informal di wilayah perkotaan (Jabodetabek) yang 
belum menjadi peserta JKN dan tidak memiliki asuransi kesehatan dari manapun.

\subsection{Pengumpulan Data}

Penelitian ini dilakukan dengan mengumpulkan data primer melalui wawancara langsung. Sebanyak 150 responden dipilih dari berbagai wilayah di Jabodetabek. Waktu pelaksanaan survei dilakukan pada bulan Oktober - November 2014. Pemilihan responden dilakukan secara purposive sampling dengan distribusi secara kuota dengan ketentuan minimal yang ditetapkan oleh peneliti dengan pertimbangan keterwakilan minimal 30 responden per kategori responden. Terkait dengan lokasi responden, peneliti tidak memberikan pembatasan khusus. Dengan demikian, sejauh responden tinggal diwilayah Jakarta dan Bodetabek dan memenuhi kriteria yang dimaksudkan dalam penelitian ini maka responden tersebut dapat diikutsertakan dalam penelitian ini. Metode untuk mendapatkan responden dilakukan secara bebas (free finding) di beberapa area perumahan dan jalan utama di Jakarta dan Bodetabek dan beberapa responden didapatkan melalui referral atau snowballing.

Untuk sebaran yang lebih baik, pekerja penerima upah dalam penelitian ini melibatkan dua kategori yaitu pekerja penerima upah tetap seperti karyawan toko, buruh, pegawai bengkel, pegawai salon dan lain-lain serta pekerja penerima upah tidak tetap seperti sopir, arsitek, pegawai lepas (freelancer), tukang dan lain-lain. Untuk pekerja penerima upah tetap diperoleh sampel sebanyak 47 responden dan pekerja penerima upah tidak tetap sebanyak 54 responden. Adapun untuk analisis secara kualitatif, diambil 6 responden yang berminat terhadap program JKN dan 6 responden yang tidak berminat terhadap program JKN untuk dianalisis secara lebih mendalam. Enam responden tersebut masing-masing diambil 2 responden dari pekerja penerima upah tetap, 2 responden penerima upah tidak tetap, dan 2 responden non penerima upah atau wiraswasta.

\subsection{Teknik Analisis Data}

Teknik analisis probit digunakan untuk mengitung probabilitas seseorang yang belum memiliki asuransi kesehatan untuk menjadi peserta JKN atau BPJS Kesehatan. Faktor yang digunakan sebagai predictor atau variabel independen adalah stimulus harga, stimulus diskon, stimulus metode pembayaran, precautionary motive, access motive, dan pengetahuan mengenai financial planning yang terdiri atas manajemen risiko, manajemen menabung, perencanaan hari tua, perencanaan harta waris, dan manajemen arus kas atau cash flow rumah tangga. Beberapa faktor demografi juga dijadikan sebagai variabel kontrol diantaranya jenis kelamin, usia, jumlah tanggungan, kelas sosial, pendidikan, pekerjaan, dan suku.

\section{HASIL DAN PEMBAHASAN}

\subsection{Pemodelan Hasil Penelitian}

Berdasarkan hasil pengolahan data dengan menggunakan probit regression, model 4.1 dalam penelitian ini menunjukkan angka Prob (LR Statistic) sebesar 0.0000 atau lebih kecil dari $\alpha=$ 0.005 . Hal yang sama juga ditunjukkan bahwa hasil Chi-Square melalui uji Goodness of Fit Test juga menunjukkan angka Probabilitas sebesar 0.0001. Dengan demikian model JKN dalam penelitian ini telah digambarkan dengan cukup baik oleh variabel-variabel bebasnya. Berdasarkan hasil regresi probit pada tabel 1, maka model JKN dapat dijelaskan dalam persamaan berikut:

$\mathrm{P}(\operatorname{JKN}(\mathrm{n}=1) !(\mathrm{n}=0))_{\mathrm{i}}=(-2.77)+0.36$ $($ Stimprice $)+1.17$ (Stimdiscount) +0.31 $($ Stimpayterm $)+0.12$ (Premotive) +1.44 (Accessmotive) +0.15 (Risk) $+(-0.46)$ $($ Saving $)+0.38$ (Retirement) $+(-0.69)$ $($ Heirs $)+0.62$ (Cashflow $)+0.35$ (Sex) + 0.006 (Age) $+(-0.03)$ (Dependant) +0.23 
$(S E C)+0.38(E d u)+(-0.007)$

(Occupation) $+(-0.47)($ Ethnicity $)+\varepsilon_{\mathrm{i}}$.

Tabel 1: Regresi Probit dan Marginal Effect Jaminan Kesehatan Nasional $(\mathrm{JKN})$

\begin{tabular}{|c|c|c|c|c|c|c|c|}
\hline \multirow{2}{*}{$\begin{array}{l}\text { JKN } \\
\text { Stim } \\
\text { price } \\
\end{array}$} & \multirow{2}{*}{$\begin{array}{c}\begin{array}{c}\text { Coef } \\
\cdot\end{array} \\
0.36\end{array}$} & \multirow{2}{*}{$\begin{array}{c}\text { Robu } \\
\text { st } \\
\text { Std. } \\
\text { Err. } \\
0.29\end{array}$} & \multirow{2}{*}{$\begin{array}{c}\mathbf{z} \\
1.27\end{array}$} & \multirow{2}{*}{$\begin{array}{c}\mathbf{P}>\mathbf{z} \\
0.20\end{array}$} & \multicolumn{2}{|c|}{$\begin{array}{c}\text { [95\% Conf. } \\
\text { Int] }\end{array}$} & \multirow{2}{*}{$\begin{array}{r}\mathbf{d y} / \\
\mathbf{d x}\end{array}$} \\
\hline & & & & & -0.20 & 0.93 & \\
\hline $\begin{array}{l}\text { Stim } \\
\text { disco } \\
\text { unt }\end{array}$ & 1.17 & 0.40 & 2.91 & $\begin{array}{l}0.004 \\
* * *\end{array}$ & 0.38 & 1.97 & 0.44 \\
\hline $\begin{array}{l}\text { Stim } \\
\text { payt } \\
\text { erm }\end{array}$ & 0.31 & 0.57 & 0.55 & 0.58 & -0.80 & 1.43 & 0.12 \\
\hline $\begin{array}{l}\text { Prem } \\
\text { otive }\end{array}$ & 0.12 & 0.40 & 0.31 & 0.75 & -0.65 & 0.90 & 0.05 \\
\hline $\begin{array}{l}\text { Acce } \\
\text { ssmo } \\
\text { tive }\end{array}$ & 1.43 & 0.40 & 3.61 & $\begin{array}{l}0.00 * \\
* *\end{array}$ & 0.66 & 2.22 & 0.53 \\
\hline Risk & 0.14 & 0.35 & 0.42 & 0.67 & -0.54 & 0.83 & 0.06 \\
\hline $\begin{array}{l}\text { Savi } \\
\text { ng }\end{array}$ & -0.46 & 0.33 & $\begin{array}{c}- \\
1.39\end{array}$ & 0.16 & -1.11 & 0.19 & $\begin{array}{c}- \\
0.17\end{array}$ \\
\hline $\begin{array}{l}\text { Retir } \\
\text { eme } \\
\text { nt }\end{array}$ & 0.38 & 0.36 & 1.06 & 0.29 & -0.32 & 1.08 & 0.14 \\
\hline $\begin{array}{l}\text { Heir } \\
\mathrm{s}\end{array}$ & -0.69 & 0.37 & $\begin{array}{c}- \\
1.86\end{array}$ & $0.06^{*}$ & -1.41 & 0.04 & $\begin{array}{c}- \\
0.27\end{array}$ \\
\hline $\begin{array}{l}\text { Cash } \\
\text { flow }\end{array}$ & 0.62 & 0.36 & 1.74 & $0.08 *$ & -0.08 & 1.33 & 0.23 \\
\hline Sex & 0.35 & 0.22 & 1.57 & 0.12 & -0.09 & 0.79 & 0.13 \\
\hline Age & $\begin{array}{c}0.00 \\
6\end{array}$ & 0.01 & 0.47 & 0.63 & -0.02 & 0.03 & 0.02 \\
\hline $\begin{array}{l}\text { Depe } \\
\text { ndan } \\
\mathrm{t}\end{array}$ & -0.03 & 0.35 & -0.1 & 0.92 & -0.72 & 0.65 & $\begin{array}{c}- \\
0.02\end{array}$ \\
\hline $\mathrm{Sec}$ & 0.23 & 0.20 & 1.17 & 0.24 & -0.16 & 0.63 & 0.09 \\
\hline Edu & 0.38 & 0.31 & 1.25 & 0.21 & -0.22 & 0.99 & 0.15 \\
\hline $\begin{array}{l}\text { Occu } \\
\text { patio } \\
\mathrm{n}\end{array}$ & $\begin{array}{c}- \\
0.00 \\
7\end{array}$ & 0.28 & $\begin{array}{c}- \\
0.03\end{array}$ & 0.98 & -0.56 & 0.54 & 0.03 \\
\hline $\begin{array}{l}\text { Ethn } \\
\text { icity }\end{array}$ & -0.47 & 0.29 & $\begin{array}{c}- \\
1.63 \\
\end{array}$ & $0.10^{*}$ & -1.04 & 0.09 & $\begin{array}{c}- \\
0.18 \\
\end{array}$ \\
\hline Cons & -2.77 & 0.64 & $\begin{array}{c}- \\
4.31 \\
\end{array}$ & 0.00 & -4.02 & $\begin{array}{c}- \\
1.51 \\
\end{array}$ & - \\
\hline $\begin{array}{l}\text { Numb } \\
\text { Obs. }\end{array}$ & of & 150 & & & & & \\
\hline $\begin{array}{l}\text { Wald } \\
(17)\end{array}$ & Chi2 & 70.28 & & & & & \\
\hline Prob > & Chi2 & 0.00 & & & & & \\
\hline Pseudo & & 0.33 & & & & & \\
\hline $\begin{array}{l}\text { Log } \\
\text { Pseude } \\
\text { ood }\end{array}$ & ikelih & $\begin{array}{l}- \\
67.34\end{array}$ & & & & & \\
\hline $\begin{array}{l}\text { Y Pr } \\
\text { (Predi }\end{array}$ & JKN) & .624 & & & & & \\
\hline
\end{tabular}

Sumber: diolah dari hasil analisis peneliti.

\subsection{Pengaruh Faktor Stimulus Terhadap Kepesertaan JKN}

Hasil regresi probit berdasarkan tabel 1 menunjukkan bahwa dari tiga variabel stimulus yang dianalisis dalam penelitian ini, ketiganya menunjukkan hubungan yang positif terhadap JKN. Dengan demikian apabila ketiga stimulus ini diberikan, yaitu harga yang lebih terjangkau, diskon pembayaran premi, dan pilihan periode pembayaran maka akan meningkatkan peluang seorang pekerja informal untuk menjadi peserta JKN. Namun demikian diantara ketiga variabel ini, stimulus diskon terhadap harga premi menunjukkan angka $\mathrm{P}$ $=0.0040$, di bawah $\alpha=0.05$ yang berarti sangat signifikan dalam mempengaruhi minat pekerja informal terhadap JKN. Dengan demikian hipotesis bahwa apabila stimulus diskon diberikan, maka minat seorang menjadi peserta JKN akan menjadi lebih besar diterima.

Data deskriptif menunjukkan bahwa faktor harga terjangkau dipertimbangkan oleh mayoritas responden (58.7\%) diikuti dengan periode pembayaran yang fleksibel $(19.3 \%)$, diskon premi $(11.3 \%)$, dan faktor lainnya sekitar $2 \%$. Sisanya sebanyak $8.7 \%$ tidak peduli dengan stimulus apapun yang diberikan oleh JKN. Berdasarkan data tersebut dapat dijelaskan bahwa pada dasarnya stimulus harga terjangkau merupakan faktor dasar yang menjadi basis pertimbangan seseorang dalam memutuskan untuk bergabung dengan JKN. Namun demikian, apabila stimulus diskon diberikan kepada calon peserta maka probabilitas seseorang tersebut menjadi peserta JKN akan menjadi paling besar. Berdasarkan data pada tabel 1, probabilitas seseorang menjadi peserta JKN jika diberikan stimulus diskon adalah sebesar $44.34 \%$ sedangkan apabila stumulus hanya diberikan berupa harga yang terjangkau maka probabilitas seseorang menjadi peserta JKN hanya $13.92 \%$ sedangkan faktor stimulus periode pembayaran 
memiliki pengaruh terhadap probabilitas menjadi peserta JKN sebesar $12.25 \%$.

Berdasarkan data di tabel 1, dapat dikatakan bahwa faktor stimulus diskon harga premi atau iuran BPJS Kesehatan akan dapat mempercepat keberhasilan program JKN pada harga yang terjangkau. Harga yang terjangkau saja tidak akan serta-merta membuat seseorang bersedia untuk menjadi peserta JKN. Adapun pada faktor periode pembayaran premi yang fleksibel, data analisis demografi menunjukkan bahwa mayoritas responden memiliki preferensi khusus terhadap alternatif periode pembayaran iuran yaitu mayoritas $74 \%$ dibayar bulanan, $7 \%$ dibayar 3 bulan sekali, $5 \%$ dibayar mingguan, dan $3 \%$ dengan periode waktu yang lebih panjang dari 3 bulan. Dengan demikian stimulus periode pembayaran yang fleksibel sesuai dengan kondisi calon peserta memiliki pengaruh yang positif terhadap minat seseorang menjadi peserta JKN.

\subsection{Pengaruh Faktor Motif Terhadap Kepesertaan JKN}

Berdasarkan hasil regresi probit pada tabel 1, precautionary motive maupun access motive memiliki nilai koefisien yang positif yang berarti keduanya berpengaruh secara positif terhadap minat pekerja informal untuk menjadi peserta JKN. Namun demikian hasil regresi probit yang ditunjukkan pada nilai $\mathrm{P}$ menunjukkan bahwa hasil signifikan hanya dimiliki oleh variabel access motive dengan nilai $\mathrm{P}$ sebesar 0.0000. Hal ini menunjukkan bahwa hipotesis yang menyatakan access motif memiliki pengaruh yang signifikan dan berhubungan secara positif terhadap JKN diterima.

Jika dilihat dari hasil pengujian yang ada pada tabel 1, probabilitas seseorang menjadi peserta JKN apabila memiliki access motive adalah sebesar $52.68 \%$. Hal ini merupakan angka yang cukup besar untuk menentukan apakah seseorang berminat terhadap JKN atau tidak. Adapun apabila seseorang memiliki precautionary motive, hal ini hanya memberikan probabilitas terhadap kepesertaan JKN sebesar $4.7 \%$.

Berdasarkan data regresi probit maupun probabilitas di atas menunjukkan bahwa kebutuhan seseorang terhadap program jaminan kesehatan bukanlah karena kesadaran seseorang yang tinggi akan perlunya berjaga-jaga akan sebuah risiko yang mungkin terjadi dimasa yang akan datang. Namun demikian, masyarakat pekerja informal lebih memikirkan bagaimana mereka memiliki akses terhadap pelayanan kesehatan. Hal ini tentu selaras dengan tujuan utama pemerintah untuk memberikan akses pelayanan kesehatan kepada seluruh penduduk Indonesia melalui sebuah program jaminan kesehatan nasional.

\subsection{Pengaruh Faktor Pengetahuan Perencanaan Keuangan Terhadap JKN}

Berdasarkan indikator hubungan dan tingkat signifikansi, variabel manajemen cash flow dan perencanaan hari tua (heirs) menunjukkan hubungan dengan JKN seperti yang diharapkan dan signifikan pada $\mathrm{P}=0.0820$ dan 0.0630 atau masih lebih kecil dari $\alpha=0.1$. Dengan demikian hipotesis terkait cash flow dan heirs diterima, sedangkan hipotesis terkait signifikansi mengenai risk, saving, dan retirement terhadap JKN ditolak.

Adapun jika dilihat dari segi probabilitas sebagaimana disajikan pada tabel 1, apabila seseorang memiliki pengetahuan mengenai perencanaan keuangan dalam hal manajemen cash flow, perencanaan hari tua (retirement) dan memiliki manajemen risiko maka probabilitas seseorang tersebut menjadi peserta JKN masing-masing secara berturut-turut sebesar $23.3 \%, 14.23 \%$, dan $5.57 \%$. Dengan demikian, terkait dengan perencanaan keuangan, kampanye JKN yang efektif dapat dilakukan terutama 
terkait dengan manajemen cash flow rumah tangga. Perencanaan yang baik mengenai cash flow akan mempengaruhi sikap seseorang tentang pentingnya jaminan kesehatan. Adapun sikap positif mengenai perencanaan hari tua juga memberikan berpengaruh terhadap sikap positif seseorang terhadap program JKN. Adapun kebiasaan seorang pekerja informal untuk menabung membuat peluang menjadi peserta JKN menjadi sebesar $-16.95 \%$ sedangkan sikap seorang pekerja informal yang sudah merencanakan harta warisan menjadikan probabilitas kepesertaan JKN menjadi $-26.72 \%$.

\subsection{Pengaruh Faktor Demografi Terhadap JKN}

Dari seluruh variabel demografi yang dievaluasi, regresi probit pada tabel 1 menunjukkan bahwa usia, SEC, dan tingkat pendidikan memiliki hubungan yang positif terhadap JKN yang ditunjukkan dengan angka koefisien yang positif. Hal ini berarti semakin tinggi usia seseorang, semakin tinggi status ekonomi sosial, dan semakin tinggi jenjang pendidikan seorang pekerja informal, maka minat orang tersebut terhadap JKN akan semakin tinggi. Beberapa variabel yang lain mengindikasikan bahwa jenis kelamin "wanita" cenderung lebih berminat terhadap JKN, orang yang memiliki "tanggungan" cenderung kurang berminat terhadap JKN begitu juga pekerja non penerima upah atau "wiraswasta" juga menunjukkan kecenderungan kurang berminat terhadap JKN. Dari aspek suku, seorang bersuku Jawa cenderung kurang berminat terhadap JKN.

Dari semua faktor demografi tersebut, jika dilihat dari hasil uji signifikansi, hanya variabel etnis yang menunjukkan hubungan yang signifikan terhadap JKN dengan $\mathrm{P}=0.1$ pada tingkat $\alpha=0.1$. Adapun hasil pengujian marginal effect yang ditunjukkan pada tabel 1 menunjukkan bahwa probabilitas yang cukup tinggi untuk menjadi peserta JKN ditunjukkan oleh faktor etnis Non Jawa (18\%), diikuti pendidikan SLTA atau lebih (14.9\%), jenis kelamin "wanita" (13.3\%), dan SEC menengah keatas $(8 \%)$. Pada variabel demografi yang lain memiliki angka probabilitas yang rendah terkait pengaruhnya terhadap JKN yaitu memiliki tanggungan keluarga $(-1.3 \%)$, pekerjaan "wiraswasta" $(-0.3 \%)$, dan usia semakin tua sebesar $0.2 \%$. Berdasarkan angka-angka tersebut menunjukkan bahwa secara umum, kecuali faktor suku, pendidikan, dan jenis kelamin faktor demografi tidak terlalu menjadi penentu terhadap minat seseorang untuk menjadi peserta JKN.

\subsection{Analisis Kebijakan Sosialisasi JKN}

Dengan mengacu pada hasil riset ini, paket premi atau harga yang terjangkau yang ditawarkan oleh pemerintah tidak serta-merta menentukan seseorang bersedia menjadi peserta JKN. Faktor diskon harga premi atau iuran dan jangka waktu berlakunya sebagaimana yang dicantumkan dalam Perpres No. 111 Tahun 2013 perlu disosialisasikan dengan baik untuk menarik minat pekerja informal untuk menjadi peserta JKN. Di luar faktor tersebut, kuatnya access motive sebagai faktor yang menentukan seseorang menjadi peserta JKN perlu ditekankan lebih kuat kembali dalam program sosialisasinya. Akses yang dimaksud adalah pelayanan kesehatan untuk manfaat pengobatan dasar, manfaat penanganan untuk penyakit khusus, pelayanan yang nyaman atau akses pelayanan kesehatan yang mudah.

Selain faktor stimulus dan motif, BPJS Kesehatan dan pihak-pihak terkait perlu juga meningkatkan edukasi terkait dengan perencanaan keuangan. Hasil riset ini menunjukkan bahwa kebiasaan pengelolaan cash flow yang baik serta perencanaan hari tua berpengaruh positif terhadap minat seseorang untuk menjadi peserta JKN. Namun demikian kebiasaan menabung justru memiliki hubungan negatif terhadap 
minat seseorang menjadi peserta JKN. Dengan demikian, secara paralel perlu adanya upaya yang lebih besar dari para pemangku kepentingan untuk kesuksesan program JKN dengan melakukan edukasi mengenai financial planning dengan baik terutama mengenai pentingnya menabung yang sejalan dengan manajemen cashflow yang baik.

Tantangan dalam melakukan sosialisasi JKN juga terjadi karena faktor demografi. Hasil penelitian ini menunjukkan bahwa perbedaan jenis kelamin, tingkat penghasilan, pendidikan, dan suku juga memiliki pengaruh terhadap minat seseorang untuk menjadi peserta JKN. Pendekatan proaktif kepada kelompok perempuan, anggota keluarga dengan pendidikan yang lebih tinggi akan meningkatkan keberhasilan program JKN khususnya pada kelompok masyarakat pekerja informal. Adapun pendekatan yang lebih persuasif dan edukatif kepada kelompok suku tertentu (misalnya suku Jawa) dan kelompok masyarakat dengan penghasilan yang lebih rendah, namun bukan penerima bantuan iuran (PBI) mutlak perlu dilakukan.

\section{KESIMPULAN DAN SARAN}

\subsection{Kesimpulan}

Hasil pengujian model dalam penelitian ini menunjukkan bahwa model regresi probit JKN dinyatakan valid dengan nilai Probability > $\mathrm{Chi}^{2}$ (0.0000), yang berarti dapat dijelaskan oleh variabelvariabel bebas yang diuji dalam penelitian ini. Berdasarkan hasil pengujian marginal effect after probit regression sebagaimana dijelaskan pada tabel 1, model ini dapat memprediksi probabilitas seorang pekerja informal menjadi peserta JKN sebesar 62.5\%. Dari kelompok variabel bebas utama yang dievaluasi yang meliputi faktor stimulus, motif pembelian (buying motive), dan perencanaan keuangan (financial planning), masing-masing faktor memiliki pengaruh terhadap minat pekerja informal terhadap JKN.

Pada aspek stimulus, tiga variabel yang diuji yaitu stimulus diskon, stimulus harga yang terjangkau dan stimulus alternatif periode pembayaran menunjukkan koefisien yang positif yang artinya masingmasing memiliki pengaruh searah terhadap minat seseorang untuk menjadi peserta JKN. Ketiganya apabila diberikan kepada calon peserta dari segmen pekerja informal akan memiliki pengaruh terhadap probabilitas menjadi peserta JKN sebesar $44.3 \%, 13.9 \%$, dan $12.3 \%$ secara berturutturut, dimana faktor diskon memiliki signifikansi sebesar $\mathrm{P}=0.0040$.

Adapun pada aspek motif, baik access motive atau motif untuk mendapatkan akses layanan kesehatan dan precautionary motive atau motif berjaga-jaga untuk risiko buruk yang mungkin terjadi dimasa yang akan datang sama-sama memiliki koefisien positif atau memiliki hubungan yang searah terhadap minat seseorang pada program JKN. Seseorang yang memiliki access motive terhadap asuransi pelayanan kesehatan memiliki probabilitas sebesar $52.7 \%$ untuk menjadi peserta JKN, sementara pada aspek precautionary motive hanya memiliki probabilitas sebesar $4.7 \%$. Faktor access motive juga memiliki hasil regresi yang signifikan pada $\mathrm{P}=0.0000$.

Pada aspek perencanaan keuangan, dari lima variabel yang dievaluasi faktor manajemen cashflow, perencanaan hari tua, dan manajemen risiko atas keadaan buruk dimasa yang akan datang sama -sama memiliki koefisien positif atau searah dengan minat seseorang menjadi peserta JKN. Masing-masing memiliki probabilitas sebesar 23.3\%, 14.2\%, dan 5.6\%. Manajemen cashflow menunjukkan hasil regresi yang signifikan pada $\mathrm{P}=0.0820$. Adapun dua variabel perencanaan keuangan yaitu perencanaan warisan (heirs) dan kebiasaan menabung (saving) memiliki koefisien negatif. Artinya jika seseorang merencanakan harta waris dan memiliki 
kebiasaan menabung, hal ini semakin membuat seseorang tidak tertarik terhadap program JKN dengan angka probabilitas masing-masing sebesar $-26.7 \%$ dan 16.95\%. Hasil regresi probit juga menunjukkan bahwa perencanaan mengenai harta waris memiliki signifikansi pada $\mathrm{P}=0.0630$.

Pada variabel kontrol demografi, terdapat dua variabel yang memiliki pengaruh probabilitas diatas $10 \%$ terhadap kepesertaan JKN yaitu tingkat pendidikan dan jenis kelamin. Pekerja informal dengan tingkat pendidikan SLTA keatas memiliki probabilitas $14.9 \%$ untuk menjadi peserta JKN, sedangkan perempuan sebesar 13.3\%. Yang menarik, seorang yang berasal dari suku Jawa memiliki probabilitas menjadi peserta JKN sebesar $-26.7 \%$ dengan tingkat signifikansi regresi probit sebesar $\mathrm{P}=0.1$. Faktor demografi lainnya tidak terlalu memberikan pengaruh terhadap minat pekerja informal pada JKN.

\subsection{Saran}

Hasil penelitian ini dapat digunakan untuk membantu pemerintah dalam hal ini BPJS Kesehatan maupun DJSN untuk melakukan intervensi kebijakan agar para pekerja penerima upah dan pekerja bukan penerima upah bersedia menjadi peserta JKN minimal untuk ruang lingkup pekerja informal perkotaan di Jabodetabek. Hasil penelitian ini menunjukkan bahwa intervensi yang paling efektif adalah melalui:

1. Memberlakukan kebijakan stimulus diskon harga premi disamping harga yang terjangkau, karena masyarakat cenderung lebih menyukai diskon yang besar diawal bergabung;

2. Meningkatkan kampanye atau sosialisasi JKN dengan pesan utama untuk memberikan akses pelayanan kesehatan (access motive) seperti layanan pengobatan dasar, pengobatan untuk penyakit khusus, pelayanan kesehatan yang nyaman, dan prosedur klaim yang mudah;

3. Melakukan edukasi financial planning atau perencanaan keuangan terutama pada aspek manajemen pengelolaan cash flow keluarga. Disamping itu perlu penyadaran kepada masyarakat pekerja informal bahwa menabung saja tidaklah cukup untuk dapat menanggung risiko dikemudian hari dan memberikan akses pelayanan kesehatan yang memadahi untuk seluruh anggota keluarga;

4. Pendekatan direct selling kepada kelompok wanita dan mereka yang berpendidikan tinggi dalam satu buah keluarga akan lebih efektif dalam menawarkan program JKN kepada suatu keluarga.

Adapun fakta demografi yang menunjukkan bahwa etnis Jawa cenderung kurang maksimal dalam menerima program JKN perlu dilakukan penelitian lebih lanjut. Hal ini mengingat bahwa intervensi secara langsung terhadap faktor demografi mustahil untuk dilakukan. Dengan demikian, pendekatan kultural yang mengutamakan kearifan sangat diperlukan untuk mensukseskan program JKN pada kelompok masyarakat yang bekerja pada sektor informal. Adapun untuk dapat diambil kebijakan secara nasional, disarankan ubtuk memperluas cakupan penelitian pada tingkat nasional.

\section{DAFTAR PUSTAKA}

Arvidsson, Sara. (2010). Essay on Asymmetric Information in the Automobile Insurance Market. Orebro: Orebro University.

Beaton, P., \& Cao. (1991). External Validity for Discrete Choice Transportation Forecasting Models Based on Stated Choice Approach, National Center for Transportation and 
Industry Productivity. New Jersey: New Jersey Institute of Technology.

Bernheim, B. D., Shleifer, A., \& Summers, L. H. (1985). The strategic bequest motive. Journal of Political Economy. 93 (6). Pp 1045-1076.

Black, Kenneth, Jr. and Skipper, Harold D, Jr. (1994). Life Insurance (12th Edition). International Edition. New Jersey: Prentice Hall, Inc.

BPJS Kesehatan. (2013). Sosialisasi Jaminan Kesehatan Nasional dan BPJS Kesehatan. Malang: BPJS Kesehatan Cabang Malang Dh. PT Askes, (Persero).

BPJS Kesehatan. (2014). Panduan Praktis Pelayanan Kesehatan. Jakarta: BPJS Kesehatan.

BPJS Kesehatan. (2014). Rekapitulasi Master File Kepesertaan BPJS Kesehatan. Tanggal 24 Oktober 2014. Jakarta: BPJS Kesehatan.

BPS (2013). Proyeksi Penduduk Indonesia 2010-2035. Jakarta:_Badan Perencanaan Pembangunan Nasional, Badan Pusat Statistik, United Nation Population Fund.

Chaudhuri, Arjun. (2006). Emotion and Reason in Consumer Behavior. London: Routledge.

Heijde, Mary van der., \& Mendonca, Daniela. (2012). Lessons from Brazil: Regulatory Changes in the Health Insurance Market. Milliman Healthcare Reform Briefing Paper. Seattle: Milliman.

Henshe, D.A., Rose, J.M., \& Greene, A.W. (2005). Applied Choice Analysis: A Primer (Vol. 1). Cambridge: Cambridge University Press.

Hubbard, R. G., Skinner, J., \& Zeldes, P. (1995). Precautionary Saving and Social Insurance. Journal of Political Economy. 103 (2). Pp 360-399.

Kertonegoro, Sentanoe. (1987). Jaminan Sosial: Prinsip dan Pelaksanaannya di Indonesia. Jakarta: Mutiara Sumber Widya.
Mahdzan, Nurul Shahnaz., \& Victorian, Sarah Margaret Peter. (2013). The Determinants of Life Insurance Demand: A Focus on Saving Motives and Financial Literacy. Canadian Center of Science and Education. Asian Social Science. Vol. 9. No. 5.

Modigliani, F., \& Brumberg, R. (1954). Utility analysis and the consumption function: an interpretration of cross section data. In K. Kurihara (Ed.), PostKeynesian Economics. New Brunswick. New Jersey: Rutgers University Press.

Munro, Dan,. (2014). U.S. Healthcare Ranked Dead Last Compared To 10 Other Countries. Forbes. http://www.forbes.com/sites/danmunro/2 014/06/16/u-s-healthcare-ranked-deadlast-compared-to-10-other-countries/.

Nyman, John A. (1999). The Value of Health Insurance: The Access Motive. Journal of Health Economics. 18. Pp 141-152.

Pearmen, D. Swanson, J., Kroes, E, Bradley, M. (1991). Stated Preference Technique, A Guide to Practice, $2^{\text {nd }}$ Edition. Den Haag: Steer Davies Gleave and Hague Consulting Group.

Peraturan Presiden No. 111 Tahun 2013 tentang JKSN.

Peraturan Presiden No. 12 Tahun 2013 tentang JKSN.

Sinaga, Hotbonar. (2009). Membangun Jaminan Sosial Menuju Negara Kesejahteraan. Bandung: Javamedia.

Solomon, Michael R. (2013). Consumer Behavior: Buying, Having, and Being (10th Edition). Global Edition. New Jersey: Pearson Prentice Hall.

Todaro, Michael P., Smith, Stephen C. (2006). Economic Development $\left(9^{\text {th }}\right.$ Edition). New York: Pearson Addison Wesley.

Undang-undang Dasar Negara Republik Indonesia Tahun 1945.

Undang-undang Republik Indonesia No. 2 Tahun 1992 Tentang Usaha Perasuransian. 
Undang-undang Republik Indonesia No. 40 tahun 2004 tentang Sistem Jaminan Sosial Nasional.

Undang-undang Republik Indonesia No. 24 Tahun 2011 Tentang Badan Penyelenggara Jaminan Sosial.

Undang-undang Republik Indonesia No. 101 Tahun 2012 Tentang Penerima Bantuan Iuran Jaminan Kesehatan.

Vasisht, A.K. (2012). Logit and Probit Analysis. New Delhi: I.A.S.R.I

World Bank. (2012). Thailand: Sustaining Health Protection for All. http://www.worldbank.org/en/news/feat ure/2012/08/20/thailand-sustaininghealth-protection-for-all. 